\title{
Global Trends in the Development of Battery-Powered Underground Mining Machines
}

doi:10.2478/mape-2021-0016

Date of submission to the Editor: 04/2021

Date of acceptance by the Editor: 06/2021

\section{Łukasz Bołoz}

ORCID ID0000-0002-7139-0558

AGH University of Science and Technology,

Poland
MAPE 2021, volume 4, issue 1, pp. 178-189

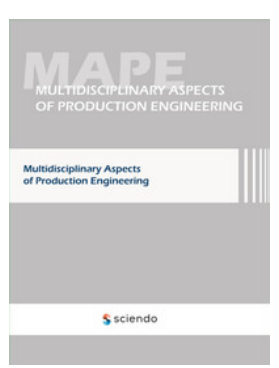

\section{INTRODUCTION}

The concept of an internal combustion or electric drive of working machines refers to complete drive units, i.e. the obtaining of mechanical energy that can be used to propel the machine's undercarriage and its working systems. Both internal combustion engines and electric motors have been known and successfully used for years in stationary and mobile machines. However, electric motors do not consume oxygen and do not emit exhaust gases, which has a positive impact on the environment and human health (Fugiel et al., 2017). They do not generate as much noise, and at the same time, they are characterized by an efficiency of more than $90 \%$, or even $98 \%$, which means that they emit much less heat. In addition, the electric drive unit is less complicated (Bołoz, 2021). Therefore, wherever mains power can be used, the electric drive wins. In the case of vehicles, mobile machines or machines working far from a source of power supply, the internal combustion engine is commonly applied. However, if we want to use battery power, which is also referred to as battery drive, additional serious problems arise. The major drawback of battery power supply is the limited range or limited operating time of the machine, especially when we take into account the long charging time. The use of additional electrically powered systems, such as lighting, air conditioning or a mechatronic system, further shortens the working time. Hence, in the case of such machines, the key issue is the management and control of the battery condition as well as optimization of battery supervision systems (Guo et al., 2021) and braking energy recovery (Polnik et al., 2020). In the case of underground mining, the operating time reduction due to low temperatures is not the only problem. Apart from the technical aspects, economic considerations related to the cost of purchase and battery operation are also extremely important (Miao et al., 2019), (Wentker et al., 2019).

Very important factors related to the underground mining of metal ores are the costs of workings ventilation, which is also designed to remove heat and eliminate the negative impact of substances produced in the process of liquid 
fuels combustion on the health of the staff working. In order to reduce the costs and improve the working conditions of the crew, it is advisable to replace diesel engines with electric motors powered from the mains and batteries. Such a tendency is observed in many countries around the world, with Canada being the precursor (Bołoz, 2021), (Electric Mine, 2021). This applies in particular to self-propelled mining machines such as drilling and bolting rigs, LHD loaders and haul trucks. It should be emphasized, however, that the user expects electrically driven machines to have the same parameters and functional properties as the ones powered by internal combustion engines. This is a serious challenge, because battery power still remains a new issue despite the fact that the electric drive is known and widely used also in mining machines. In addition, it should be noted that the difficulty results, in particular, from the specific conditions of underground mining and related requirements.

Designing machines for underground mining requires the use of modern methods that allow meeting the requirements of users, while taking into account extremely difficult working conditions (Bołoz and Castaneda, 2018), (Bołoz, 2020a). Battery operation of machines poses an additional design and economic challenge (Burd et al., 2020). Challenges in the design of modern machines intended for underground work also involve aspects related to occupational safety and health, including the increasingly discussed problem of excessive noise (Biały et al., 2021), as well as problems related to the rapidly developing robotization, automation (Bołoz and Biały, 2020) and digitization (Kozłowski and Wojtas, 2017), (Wojtas et al., 2017). Self-propelled drilling and bolting rigs perform drilling and bolting, which belong to the basic processes applied in the room and pillar mining system. In the case of these machines, the above mentioned processes determine the working systems power demand. The bolting process is necessary and allows controlling the excavation stability (Skrzypowski, 2020), (Skrzypkowski et al., 2020). Drilling is carried out in the case of both drilling and bolting rigs. The energy consumption and efficiency of the drilling process depends on many factors, especially on the drilling method, hole diameter, type and condition of the tool as well as the physical and mechanical properties of the rock (Bołoz, 2020b), (Kotwica and Małkowski, 2019), (Stopka, 2020), (Stopka et al., 2021).

\section{ARTISAN MACHINES}

Many manufacturers around the world offer battery-powered electric machines for underground mining. Currently, none of the manufacturers has the entire fleet of machines in the battery-operated version, but many of them already offer several models and types of machines.

Artisan is now part of Sandvik. Artisan introduced a battery drive in 2011. Currently, it offers 3 models of machines: two LHD loaders identified as A4 and A10, and a Z50 haul truck (Fig. 1). 


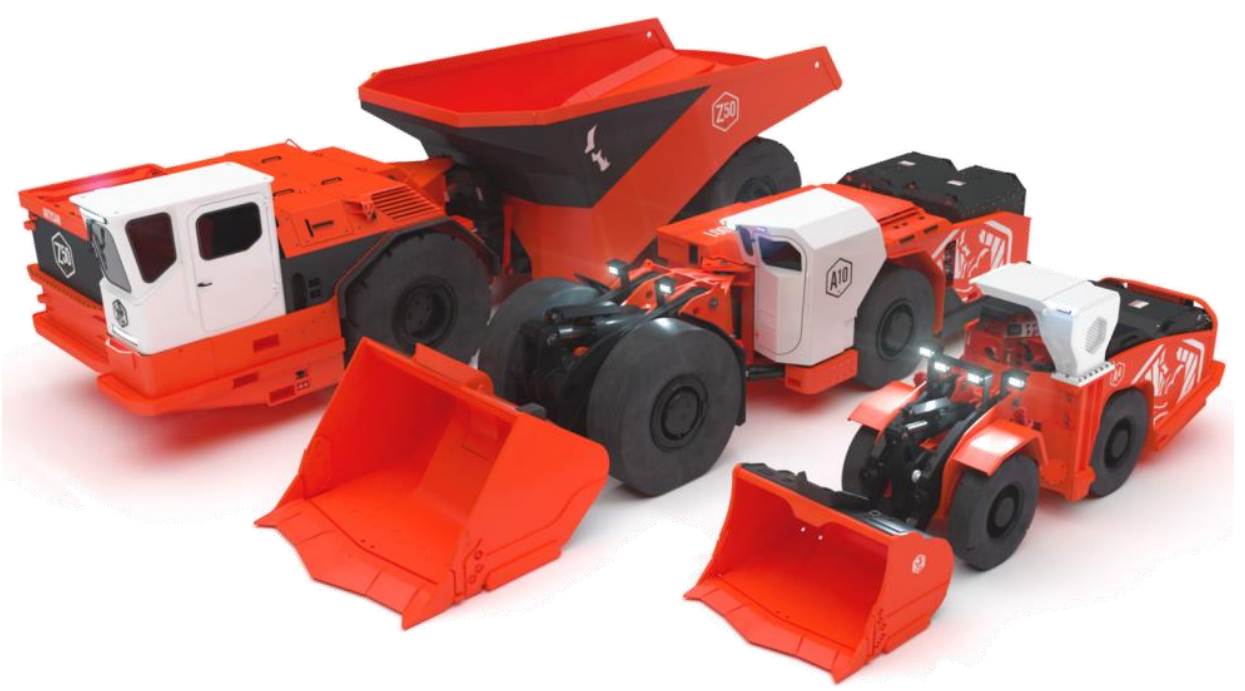

Fig. 1 Artisan battery-powered haul truck and LHD loaders

The smallest Artisan A4 loader, with a capacity of 4 tons, has a $150 \mathrm{~kW}$ motor for the chassis and a $100 \mathrm{~kW}$ one for the hydraulic system. The machine is equipped with a 145 Ah battery, with an option of 220 Ah. The A4 loader is 1 meter shorter than the competing combustion versions. In addition, it is very narrow - its width reaches $1.65 \mathrm{~m}$, and its own weight is less than $11 \mathrm{Mg}$. The A4 loader is optionally available in a two-speed version. As standard, it has braking energy recovery, and the batteries allow working on a single charge throughout the shift.

The A10 loader is much larger; it has a load capacity of $10 \mathrm{Mg}$ and is equipped with two motors with a power of $480 \mathrm{~kW}$ and $125 \mathrm{~kW}$, respectively, for driving and the hydraulic system. The chassis motors drive the front and rear axles separately. The loader has two batteries with a capacity of $440 \mathrm{Ah}$ and $70 \mathrm{Ah}$. From the very beginning, It was designed for battery operation. As a result, it weighs about $33 \mathrm{Mg}$ - slightly more than the competing internal combustion loaders, but it is much smaller. The Z $Z 50$ haul truck is currently the world's largest battery-operated truck with a capacity of $50 \mathrm{Mg}$. Its curb weight is over $48 \mathrm{Mg}$. It has four chassis motors, built in the wheel hubs, with a total power of $980 \mathrm{~kW}$, as well as an auxiliary motor of $125 \mathrm{KW}$ for the hydraulic system. Similarly to the A10 loader, it is equipped with two batteries: the main battery with a capacity of 576 Ah and the auxiliary 72 Ah one.

The two largest Artisan machines, i.e. the Z50 truck and the A10 loader, have a quick battery replacement system (Fig. 2). The entire journey to the place of battery storage does not exceed 7 minutes. Both machines have a built-in, integrated system for lowering, lifting and locking the battery. During battery replacement, the machines work on auxiliary batteries. Batteries can be charged with a fast charger from zero to at least $60 \%$ in 15 minutes. Artisan uses $\mathrm{LiFeP}_{4}$ lithium-iron-phosphate batteries. 

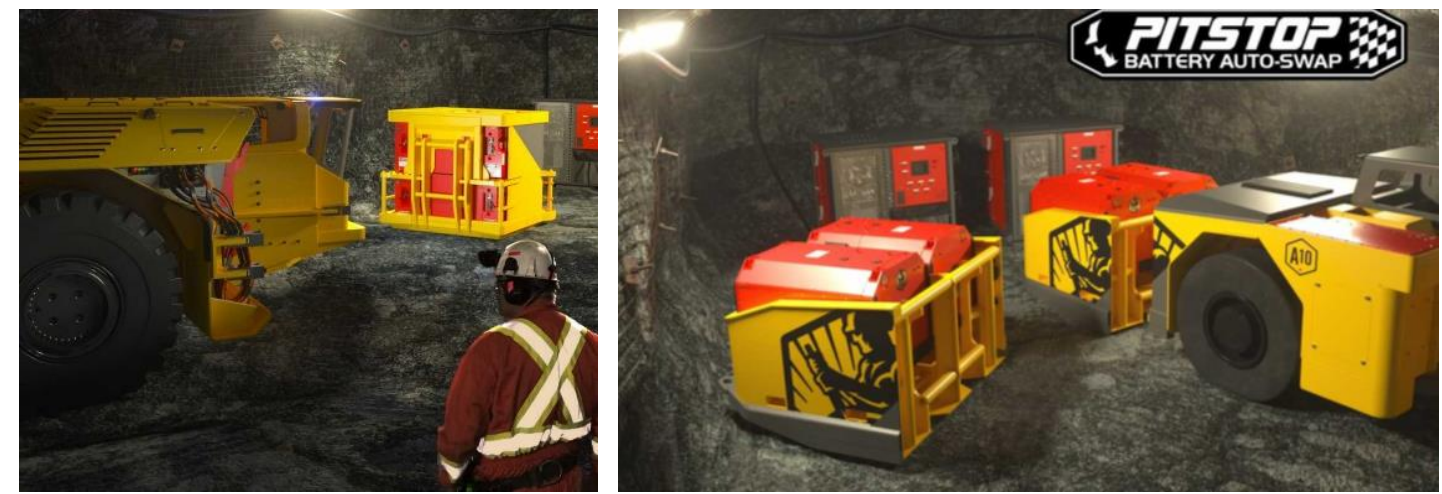

Fig. 2 Artisan quick battery replacement system - auto swap

\section{SANDVIK MACHINES}

Sandvik has been offering battery-powered machines for underground mining since 2016. The LH518B loader has a capacity of $18 \mathrm{Mg}$. The front axle is powered by two $180 \mathrm{~kW}$ motors, each, and the rear axle by one such motor. Additionally, the hydraulic system is driven by two motors, $100 \mathrm{~kW}$ each. Sandvik designs battery-powered machines from scratch, avoiding the adaptation of internal combustion machines to battery power. The own weight of the LH518B loader is $52 \mathrm{Mg}$, i.e. approximately $5 \mathrm{Mg}$ more than the similar one with a combustion engine, but at the same time it is noticeably lower and narrower.

In its earlier LH307B battery-operated loader, Sandvik used LTO lithium-titanium oxygen and fast charge batteries without battery replacement. However, in the current version, it applies Artisan batteries and their charging system, which, using a $2 \times 180 \mathrm{~kW}$ charger, charges the battery from zero to $100 \%$ in approximately 60 minutes. The LH518B loader uses two main batteries and an auxiliary battery with a total capacity of $576 \mathrm{Ah}$. The auxiliary battery, like in Artisan machines, is used to power the machine during battery replacement. The battery replacement process for the LH518B loader does not exceed 5 minutes (Fig. 3).
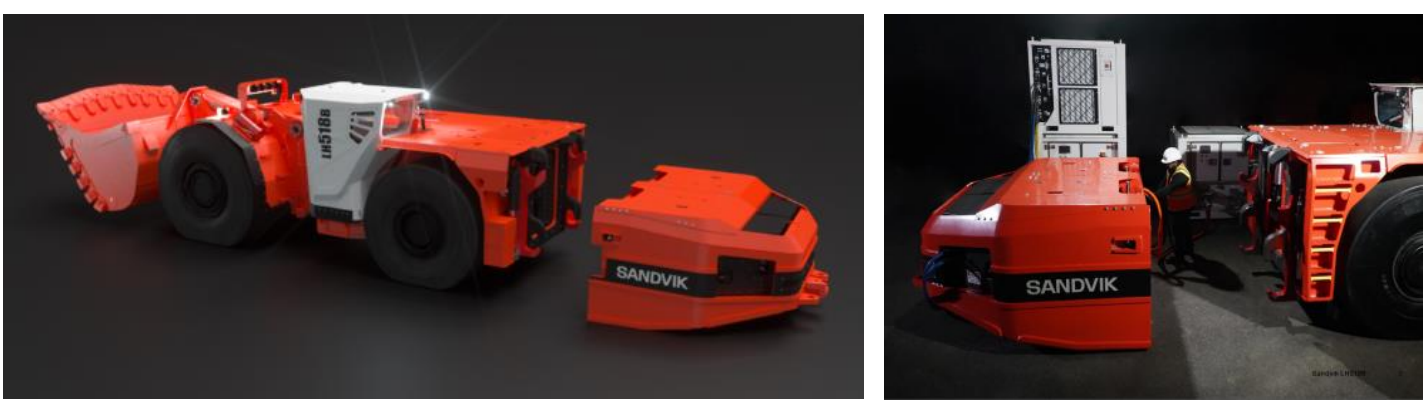

Fig. 3 LH518B loader with a quick battery replacement system

Another Sandvik battery-powered machine is the DD422iE drilling rig from 2016. The DD422iE rig has a double-boom design and covers up to $60 \mathrm{~m}^{2}$ (Fig. 4). It has fewer than half hydraulic hoses as compared to the combustion version. In total, the length of the hydraulic lines has been reduced from 240 to 100 metres. 
The DD422iE machine uses $\mathrm{NaNiCl}_{2}$ sodium-nickel-chlorine batteries. The machine is recharged while drilling. The batter enables covering $24 \mathrm{~km}$ on a flat terrain, and in the case of the terrain slope reaching 8-steps, i.e. 14 percent, it covers nearly $4 \mathrm{~km}$.

Another Sandvik machine is an ultra-low, radio-controlled bulldozer, which fits in a one-metre high excavation (Fig. 4). With a power of $60 \mathrm{~kW}$ and a pressure force of $4 \mathrm{Mg}$, it can work on a single charge for up to 5 hours. The bulldozer is equipped with 230 Ah sodium-nickel-chlorine batteries.

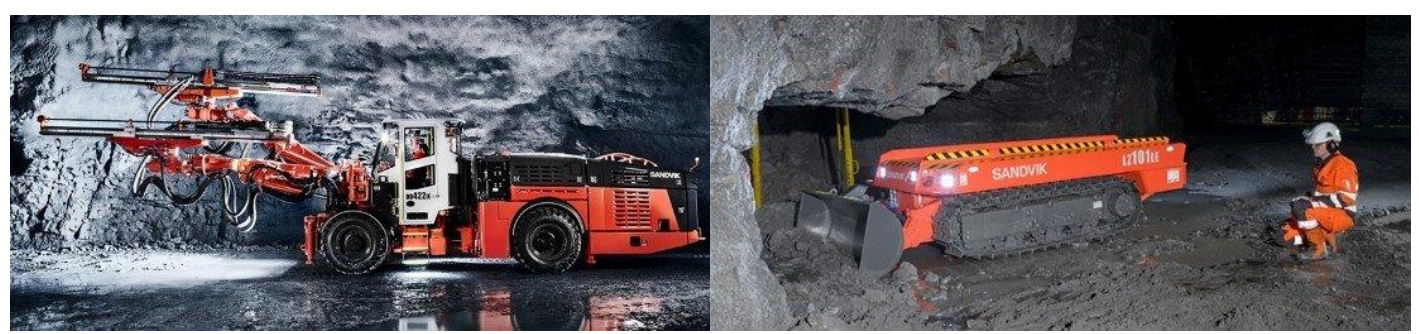

Fig. 4 DD422iE drilling rig and the LZ101LE ultra-low bulldozer produced by Sandvik

\section{EPIROC MACHINES}

Epiroc, or the former Atlas Copco, has a fairly wide range of battery-operated machines for underground mining (Fig. 5). Epiroc started its adventure with the battery drive in 2016 as Atlas Copco, offering the LHD ST7 loader with a capacity of $7 \mathrm{Mg}$. Epiroc has announced that by 2025 it will have offered all machines in battery-operated versions. Currently, Epiroc's offer for underground mining includes two drilling rigs, one haul truck, an LHD loader, two bolting rigs and four raiseboring rigs. All the machines are labelled with a model designation and the word "Battery", which dispels doubts about the power source.
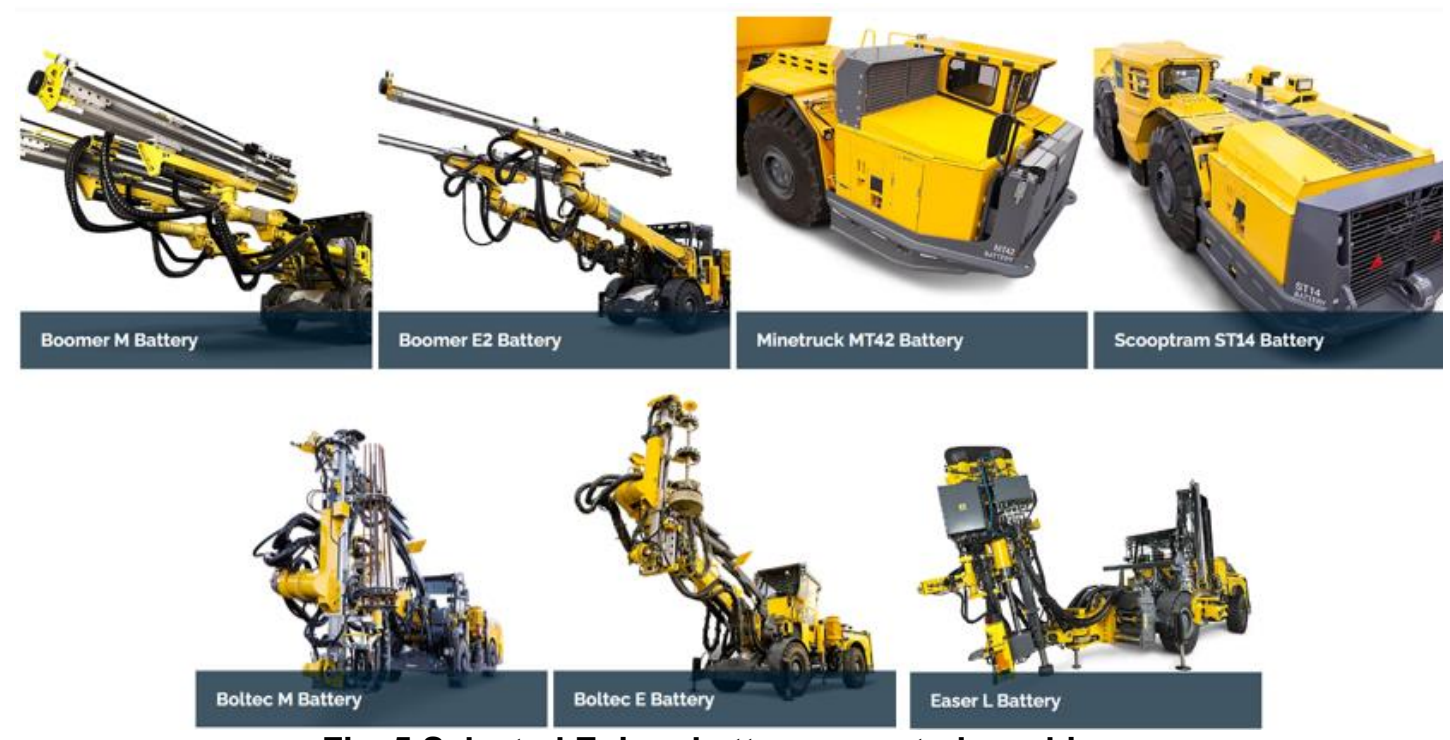

Fig. 5 Selected Epiroc battery-operated machines

The Boomer drilling rigs have been on the market since 2018. They are available in a two-boom version with a chassis electric motor having a power of $150 \mathrm{~kW}$. 
The $M$ series is designed for a face of up to $65 \mathrm{~m}^{2}$, and the $E$ series - for a face reaching max. $112 \mathrm{~m}^{2}$. Both series are also available in combustion versions with a $120 \mathrm{~kW}$ diesel engine. According to Epiroc, the electric motor, despite being more powerful than the internal combustion engine, generates $80 \%$ less heat. The diesel versions are also available as single-boom trucks. The batteryoperated versions, apart from driving motors, are additionally equipped with two $55 \mathrm{~kW}$ electric motors to propel other systems. The combustion and batteryoperated versions have the same key parameters, including dimensions, weight and turning radius. Both the $E$ and $M$ series are equipped with 280 Ah main batteries and built-in chargers. In 2018, the first versions had $88 \mathrm{kWh}$ batteries, which allowed the largest machine weighing $40 \mathrm{Mg}$ to cover $15 \mathrm{~km}$ on a flat road. The Botlec $\mathrm{E}$ and $\mathrm{M}$ bolting rigs differ in the maximum height of the excavation in which they can work and in the length of the bolts. The smaller $\mathrm{M}$ bolting rig installs 1.5 to $3.5 \mathrm{~m}$-long bolts in workings of up to $9.5 \mathrm{~m}$. The larger one $-\mathrm{E}$ bolting rig has bolts with a length ranging from $2.4 \mathrm{~m}$ to $6 \mathrm{~m}$, and can be used in workings having a height of up to $13 \mathrm{~m}$. These rigs are also available in diesel versions. The battery-powered units have $150 \mathrm{~kW}$ chassis motors and additional motors with a maximum power of $83 \mathrm{~kW}$. Both series are equipped with main 280 Ah batteries and built-in chargers. In the case of bolting rigs, the combustion versions have the same dimensions, but are $2 \mathrm{Mg}$ lighter.

The Scooptram ST14 loader has a load capacity of $14 \mathrm{Mg}$, a $200 \mathrm{~kW}$ engine and a $160 \mathrm{~kW}$ hydraulic system, whereas the haul truck has a load capacity of 42 $\mathrm{Mg}$, two chassis motors, $200 \mathrm{~kW}$ each, and a $160 \mathrm{~kW}$ hydraulic system motor. The weight of both machines is similar, reaching 42 and below $38 \mathrm{Mg}$, respectively. The manufacturer does not specify the power or capacity of the battery. In both machines, a battery replacement system has been applied (Fig. 6). However, it requires external infrastructure as the machines do not have an appropriate mechanism or a backup power source. Both machines can be recharged with an external charger, without the necessity to remove the battery. NMC - nickel, manganese, cobalt lithium-ion batteries have been applied. Epiroc reports that the batteries used in the LHD loader can be charged from zero to $90 \%$ in 50 minutes, and in the case of the haul truck - in 120 minutes.
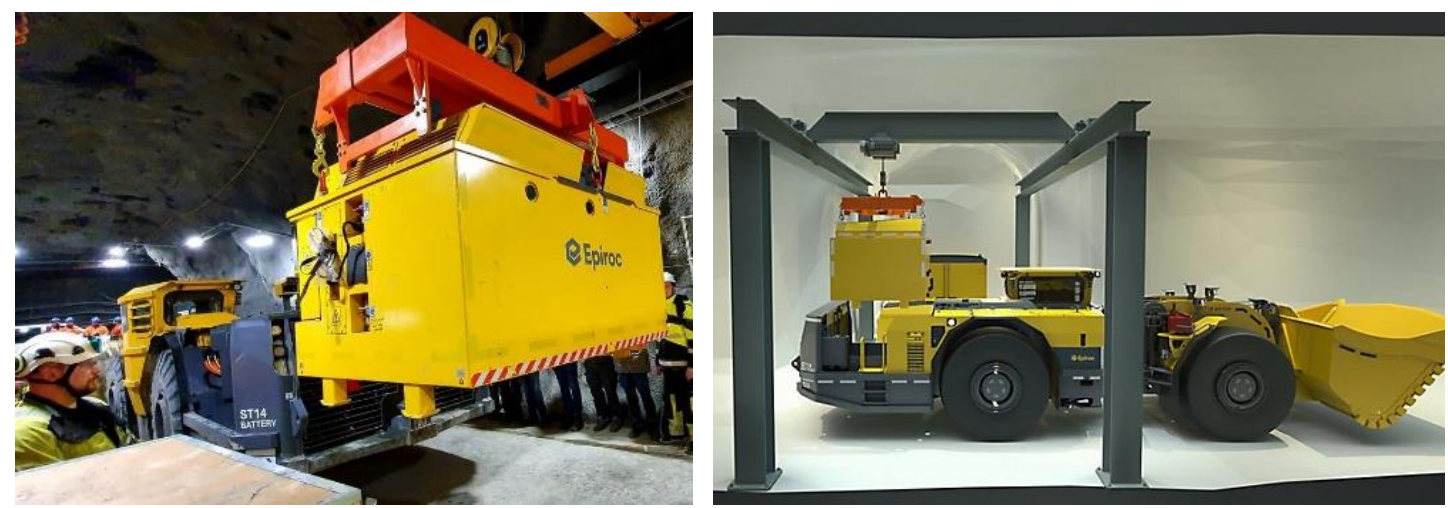

Fig. 6 Epiroc battery replacement system 


\section{KOMATSU (JOY) MACHINES}

In the case of battery-operated machines, Komatsu uses technologies developed by Joy. Hence, the offer includes several battery-powered haul trucks. Since 2020, Komatsu companies have been announcing their plan to apply battery power in loaders as well as in drilling and bolting rigs. However, unit present, no specific information about it has been provided.

Regardless of the battery drive, Komatsu is launching drilling rigs with the number of hydraulic hoses reduced to 6 , and is also planning a version where all hoses will be routed inside the boom and guide frame. Fig. 7 shows the most advanced ZJ32Bi battery-operated drilling rig in the so-called hoseless version, i.e. without hydraulic hoses. In addition, Komatsu is intending to introduce farreaching modularity, where it is possible to configure two machines that differ only in the working element (bolting, drilling). Modularity will also apply to other components, such as cabins, control panels or drills.

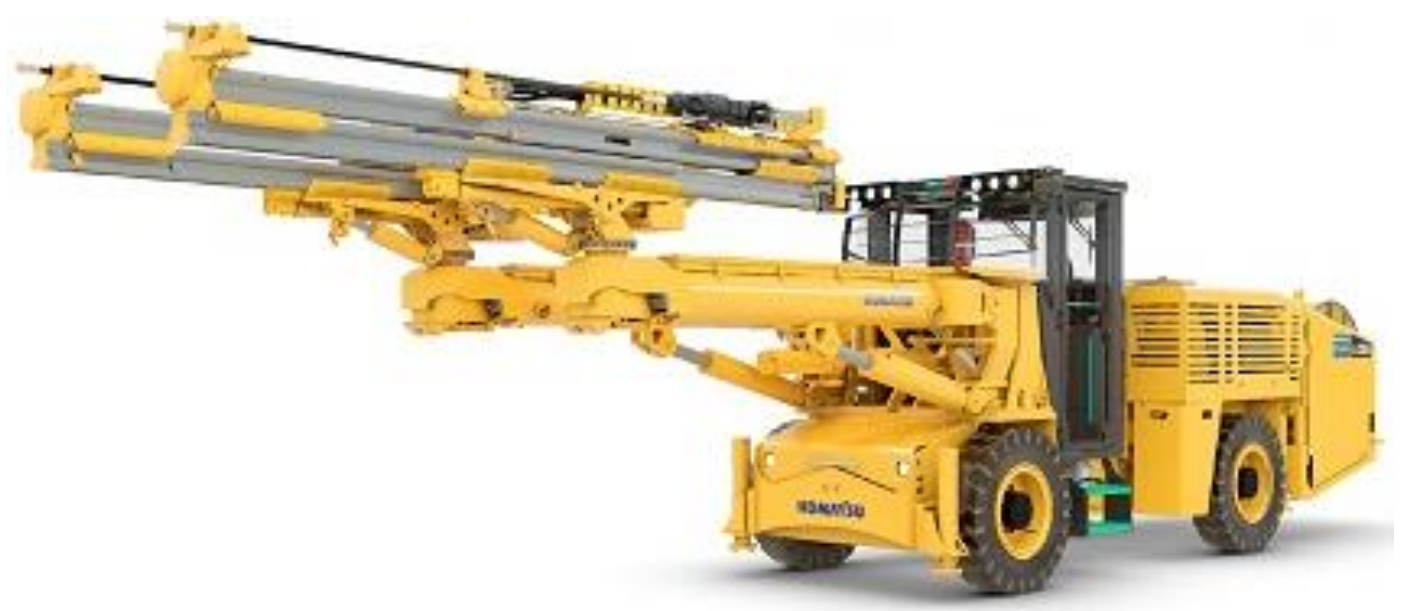

Fig. 7 Komatsu ZJ32Bi battery-operated drilling rig

Joy battery-operated haul trucks are currently available for load capacities ranging from $8 \mathrm{Mg}$ to $30 \mathrm{Mg}$ for shuttle cars and from $11 \mathrm{Mg}$ to $30 \mathrm{Mg}$ in case of haulers. They are designed to work in low, medium and high workings. Battery haulers are available in versions powered by $128 \mathrm{~V}$ DC or $240 \mathrm{~V} \mathrm{AC.}$

Joy uses a patented battery replacement system that does not require any extra infrastructure (Fig. 8). Additionally, Joy offers a battery pick-up and transport system as an attachment to be installed on an auxiliary machine in order to move and prepare the battery. The batteries are installed on a so-called battery carousel. The carousel holds 3 batteries and is electrically powered. Its size allows it to be left in a normal excavation. The operator disconnects the cable from the removed battery and connects it to the charged one. Data concerning the system or batteries themselves is not available. 

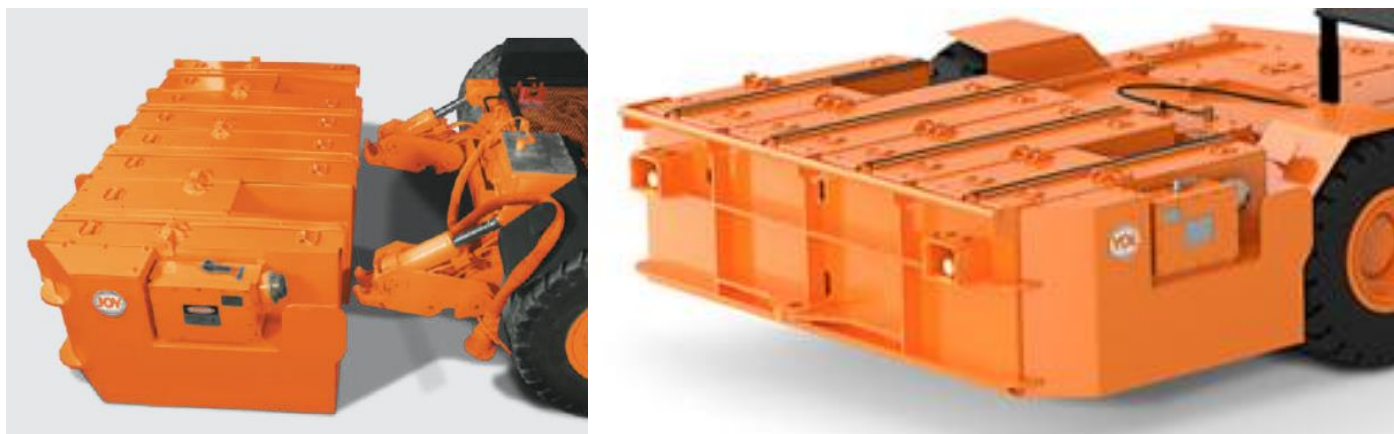

Fig. 8 Komatsu battery replacement system (Joy)

\section{MACHINES PRODUCED BY OTHER COMPANIES}

Despite being the most famous in the world, the presented manufacturers are not the only companies producing battery-operated machines. Aramine developed the first L120B battery-operated loader in 2016. Its successor, the L140B loader, whose width is only $1.1 \mathrm{~m}$, has been designed mainly for intrusion-related deposits. The Aramine loader is available with an integrated charger, and since 2020 - with a QRS system, which is a patented Quick Replacement System, allowing for battery replacement in less than 15 minutes. However, the QRS requires the use of appropriate additional infrastructure. Batteries are charged with external chargers. Aramine is currently working on the L350B loader, which will have a bucket capacity of approximately $5 \mathrm{~m}^{3}$.
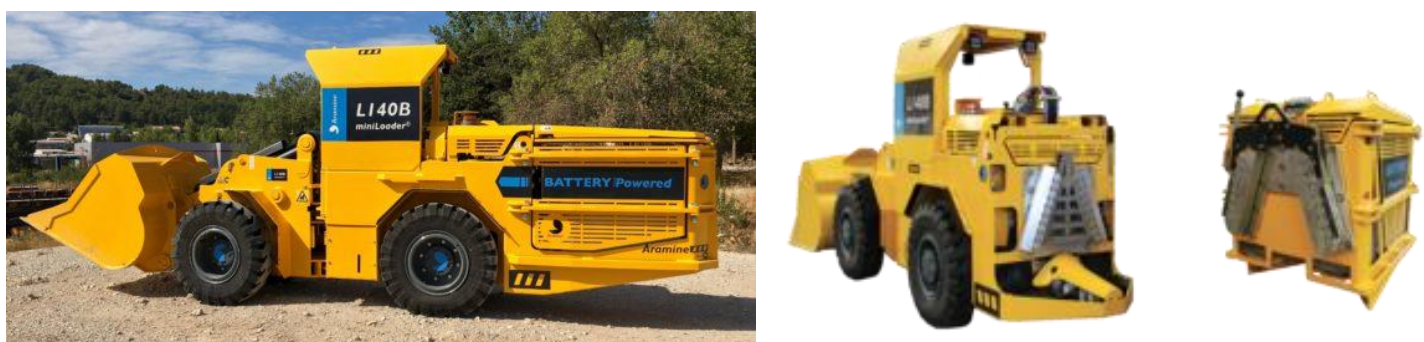

Fig. 9 Aramine L140B loader and QRS battery replacement system

Another manufacturer - MacLean produces very many battery-powered electric machines: auxiliary machines, transporting, chipping, shotcreting machines, machines for crushing oversized lumps and others. MacLean launched the first battery-powered machines in 2015, and it has sold over 30 units on the Canadian market. MacLean machines have a 4-wheel drive, an independent drive on both axles and brake energy recovery.

Normet company, similarly to MacLean, mainly offers auxiliary machines. Normet started working on battery power in 2015 and, based on the self-created SmartDrive, developed battery-powered auxiliary vehicles: for transporting shotcrete, for shortcreting, for preparing and transporting emulsion explosives, a multifunctional transport vehicle, an auxiliary truck with a raised platform and a shooting cart (Fig. 10). 

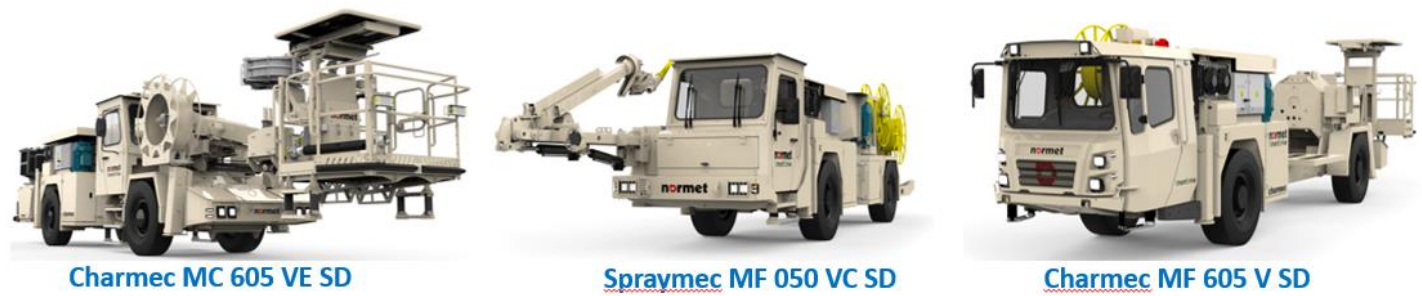

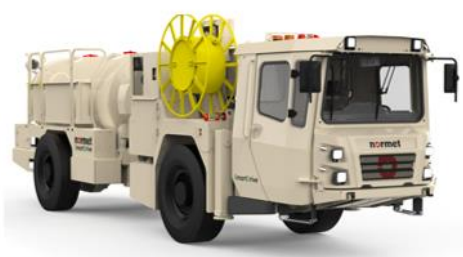

Utimec MF 500 Transmixer SD

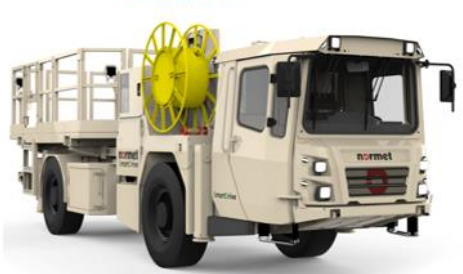

Utilift MF 540 SD

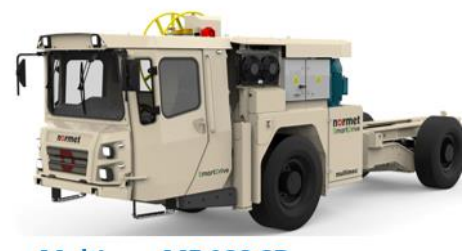

Multimec MF 100 SD

Fig. 10 Selected battery-operated machines produced by Normet

All Smart Drive machines have a four-wheel drive with braking energy recovery. A separate electric motor has been used for each axle. The Smart Drive system includes mobile and stationary chargers. The fast charge stationary versions are available in two variants, $150 \mathrm{~kW}$ and $300 \mathrm{~kW}$. The chargers are adapted to the mine's power network. Instead of battery replacement, Normet applies fast charge with the possibility of recharging during work or breaks. The machines use LTO lithium-titanate batteries. Normet machines are equipped with built-in fast chargers that charge the battery from zero to $80 \%$ in 2.5 hours. When external chargers are used, this time can be shortened even to thirty minutes. Medatech, on the other hand, offers a complete AltDrive system as an option that allows changing the combustion-engine drive for a battery-powered one. This is a very interesting solution for the transition phase, when users have many fully operational combustion machines. Medatech is responsible for the effective introduction of the battery drive in MacLean machines.

\section{CONCLUSION}

Battery-powered mining machines do not have a very long history. They are still in development and there are still many problems to be solved. With hydrogen propulsion on the horizon, Komatsu has already announced the use of hydrogen in all its trucks in the near future. However, battery power in underground mining machines is still posing a problem. Braking energy recovery is applied in most machines. The standard versions of drilling and bolting rigs are equipped with built-in, integrated chargers that allow recharging the battery at the workstation, even during work. Fast charging systems are used for typical vehicles, such as LHD loaders and haul trucks. Most manufacturers of LHD loaders and haul trucks also offer battery replacement by means of independent lifting devices or with the use of built-in, integrated mechanisms, which during the main battery replacement are powered by the auxiliary battery. However, simulation tests carried out for a haul truck with a capacity of $40 \mathrm{Mg}$ indicate the advantage of fast charging over battery replacement. In the analysed studies, fast charging generates $48 \%$ lower costs in a five-year perspective. The results depend on 
specific conditions, i.e. the adopted assumptions, so these differences may vary from mine to mine (Rafi et al., 2020).

The values of power of the electric motors used range from several dozen, usually from $100 \mathrm{~kW}$, to a total of more than one megawatt. These machines use batteries with a capacity ranging from several dozen, usually around 200 Ah, to a total of even $580 \mathrm{Ah}$. The battery energy for a typical voltage of $600 \mathrm{~V}$ to $700 \mathrm{~V}$ ranges between $100 \mathrm{kWh}$ and $350 \mathrm{kWh}$.

Companies such as Epiroc or Sandvik have recently extended their offer with the possibility of leasing or even purchasing batteries on a repair and maintenance service basis, which is a novelty, but may become very popular among users due to the price of batteries.

Machines designed from the outset with electric and battery operation in mind are slightly heavier, but smaller than the combustion versions. On the other hand, battery-powered machines based on the design of internal combustion machines are of a similar weight or heavier with the same dimensions. Until a few years ago, each manufacturer started their adventure with battery power from the smallest machines, whereas currently there are solutions with huge powers used in 50-ton haul trucks or 18-ton loaders.

Recent years have seen an increased interest in electric battery drives, which are also applied in places where until present only internal combustion engines have been used. This is due to many reasons, but the most important ones are related to ecology and working conditions. The growing experience of producers and better batteries allow us to be optimistic about the further development of battery machines, also in underground mining.

Polish company Mine Master also offers two battery-powered machines, the Roof Master RM 1.8KE bolting rig and the Face Master FM 1.7LE drilling rig. Both machines follow global trends, have built-in chargers, the possibility of recharging at the workstation and braking energy recovery.

\section{ACKNOWLEDGEMENT}

The research was conducted with the support of the statutory work project number POIR.01.01.01-00-D011/16 „Nowa generacja modułowych maszyn, wiercącej $i$ kotwiącej, z napędami bateryjnymi, przeznaczonych do pracy $w$ podziemnych kopalniach rud miedzi i surowców mineralnych” („New generation of modular machines - a drilling and bolting rig, with battery drives, intended for work in underground mines of copper ores and mineral resources").

\section{REFERENCES}

Biały, W., Bołoz, Ł. and Sitko, J. (2021). Mechanical processing of hard coal as a source of Noise pollution. Energies, 14, pp. 1-14.

Bołoz Ł. \& Castañeda Leonel F. (2018). Computer-aided support for the rapid creation of parametric models of milling units for longwall shearers, Management Systems in Production Engineering, 26(4), pp. 193-199.

Bołoz, Ł. (2020a). Digital Prototyping on the Example of Selected Self-Propelled Mining Machines. Multidisciplinary Aspects of Production Engineering, 3(1), pp. 172-183. 
Bołoz, Ł. (2020b). Interpretation of the results of mechanical rock properties testing with respect to mining methods. Acta Montanistica Slovaca, 25(1), pp. 81-93.

Bołoz, Ł. (2021). Światowe trendy w rozwoju podziemnych maszyn górniczych z napędami bateryjnymi, VI Science Symposium: Rozwój i eksploatacja maszyn górnictwa podziemnego surowców mineralnych - efekty współpracy przemysłu i nauki. (online symposium).

Bołoz, Ł. \& Biały, W. (2020). Automation and Robotization of Underground Mining in Poland. Applied Science, 10, pp. 1-14.

Burd, JTJ., Moore, EA., Ezzat, H., Kirchain, R. and Roth, R. (2020). Improvements in electric vehicle battery technology influence vehicle lightweighting and material substitution decisions. Applied Energy, 12.

Electric mine. (2018). The 100\% electric mine - Converting the biggest diesels to electric. Available online: https://www.nrcan.gc.ca/science-and-data/fundingpartnerships/funding-opportunities/current-investments/the-100-electric-mineconverting-the-biggest-diesels-electric/22639 [accessed 22 March 2021].

Fugiel, A., Burchart-Korol, D., Czaplicka-Kolarz, K. and Smoliński A. (2017). Environmental impact and damage categories caused by air pollution emissions from mining and quarrying sectorsof European countries. Journal of Cleaner Production, 143, pp. 159-168.

Guo, YJ., Yang, ZL., Liu, KL., Zhang, YH. and Feng, W. (2021). A compact and optimized neural network approach for battery state-of-charge estimation of energy storage system. Energy, 219, pp. 1-10.

Kotwica, K. \& Małkowski, P. (2019). Methods of Mechanical Mining of Compact-Rock - A Comparison of Efficiency and Energy Consumption. Energies, 12, pp. 1-25.

Kozłowski, A. and Wojtas, P. (2017). Systemowe podejście do cyfryzacji w procesach technologicznych w górnictwie. Zeszyty Naukowe Instytutu Gospodarki Surowcami Mineralnymi i Energią Polskiej Akademii Nauk, 99, pp. 47-56.

Miao, Y., Hynan, P., Jouanne, A. and Yokochi, A. (2019). Current Li-lon Battery Technologies in Electric Vehicles and Opportunities for Advancements. Energies, 12, pp. 1-20.

Polnik, B., Kaczmarczyk, K., Niedworok, A., Baltes, R. and Clausen, E. (2020). Energy Recuperation as One of the Factors Improving the Energy Efficiency of Mining Battery Locomotives. Management Systems in Production Engineering, 28(4), pp. 253-258.

Rafi, M. A. H., Rennie, R., Larsen, J. and Bauman, J. (2020). Investigation of Fast Charging and Battery Swapping Options for Electric Haul Trucks in Underground Mines. 2020 IEEE Transportation Electrification Conference \& Expo (ITEC), Chicago, IL, USA, pp. 1081-1087.

Skrzypkowski, K. (2020). Case Studies of Rock Bolt Support Loads and Rock Mass Monitoring for the Room and Pillar Method in the Legnica-Głogów Copper District in Poland. Energies, 13, pp. 1-20.

Skrzypkowski, K., Korzeniowski, W., Zagórski, K. and Zagórska, A. (2020). Adjustment of the Yielding System of Mechanical Rock Bolts for Room and Pillar Mining Method in Stratified Rock Mass. Energies, 13, pp. 1-20.

Stopka, G. (2020). Laboratory research on the influence of selected technological parameters on cutting forces during hard rock mining with asymmetric disc tools. Acta Montanistica Slovaca, 25(1), pp. 94-104.

Stopka, G., Kotwica, K. and Prostański, D. (2021). Study and application of asymmetrical disk tools for hard rock mining, Energies, 14, pp. 1-21.

Wentker, M., Greenwood, M. and Leker, J. (2019). A Bottom-Up Approach to LithiumIon Battery Cost Modeling with a Focus on Cathode Active Materials. Energies, 12, pp. 1-18.

Wojtas, P., Kozłowski, A. and Wojtas, M. (2017). Digitization of Polish mining industry by reducing costs and improving safety and quality of finished product, Mininig Informatics Automation and Electrical Engineering, 3(531), pp. 57-66. 
Abstract: The growing requirements and needs of users as well as a strong emphasis on pro-ecological solutions cause an increasing interest in battery-powered electric mining machines. Internal combustion machines consume oxygen, generate noise, fumes and heat, which affects work in underground mines, and minimizing these factors is expensive. Battery solutions allow achieving the same operational parameters of machines with significantly higher safety, comfort and work culture. The problem, however, is their range or working time. The article presents global trends in the development of battery-operated machines for underground mining. Various machines in battery-powered versions have been presented. The applied solutions have been discussed, especially in the field of battery replacement or recharging and braking energy recovery. Manufacturers around the world offer more and more battery-powered machines. Some producers are announcing complete replacement of combustion solutions with electric ones within the next few years. There are also hydrogen machines on the horizon, which will probably be the next step on the road to a zero-emission industry.

Keywords: self-propelled mining machines, battery power, battery drive, underground mining, braking energy recovery, battery replacement 